\title{
Is the single variant form of Plasmodium vivax Duffy binding protein-II (PvDBP-II) adequate for inclusion in a PvDBP-II-based vaccine?
}

\author{
Vahideh Valizadeh, Sedigheh Zakeri, Akram Abouei Mehrizi, Navid Dinparast Djadid \\ From Challanges in malaria research: Core science and innovation \\ Oxford, UK. 22-24 September 2014
}

The binding domain of Duffy protein (DBP-II) is a leading vaccine candidate of Plasmodium vivax. In order to develop a successful vivax malaria vaccine based on DBPII, the antigenic diversity and also naturally occurring functional antibodies to different PvDBP-II variant types in the various populations must be known. To define whether the polymorphisms in PvDBP-II influenced the nature of functional antibody responses, this investigation was designed to evaluate naturally acquired antibodies to five circulating variant forms of DBP-II antigens in infected individuals with $P$. vivax living in hypoendemic areas in Iran. Sequence diversity of $p v d b p-I I$ gene was performed in 63 Iranian $P$. vivax isolates collected during 2008-2012. The sequencing analysis showed twenty two single nucleotide polymorphisms in PvDBP-II, resulting in 16 different haplotypes among the Iranian $P$. vivax isolates. Five of 16 genetically distinct variants were expressed in $E$. coli, and anti-DBP-II responses were measured in $P$. vivax -infected individuals $(\mathrm{n}=202)$. Also, by performing immune-depletion ELISA experiments, antibody responses to the conserved sites of all five allelic forms were evaluated using the corresponding and non-corresponding patients' sera $(n=20)$. ELISA results revealed that naturally acquired anti-PvDBP-II IgG were recognized all five expressed variant forms with no statistically difference $(P>0.05$, Cochran's $\mathrm{Q}$ test). The antibody depletion experiments also showed presence of the cross-reactive antibody responses to heterologous variants of PvDBP-II in Iranian individuals who were infected with distinct allelic forms of the PvDBP-II. Finally, all five examined variant forms of DBP-II were expressed transiently on the surface of COS-7 cells to determine whether people exposed to

Malaria and Vector Research Group (MVRG), Biotechnology Research Center (BRC), Pasteur Institute of Iran, Tehran, Iran vivax malaria acquire antibodies that have the ability to block erythrocyte cytoadherence to PvDBP-II. The antiDBP-II IgG block heterologous and homologous expressed DBP-II function, indicating that the protective immunity against PvDBP-II binding is not strain specific. In conclusion, the present results indicate that the single variant of PvDBP-II is adequate to be included in a PvDBP-II-based vaccine.

Published: 22 September 2014

doi:10.1186/1475-2875-13-S1-P95

Cite this article as: Valizadeh et al:: Is the single variant form of Plasmodium vivax Duffy binding protein-II (PvDBP-II) adequate for inclusion in a PvDBP-II-based vaccine? Malaria Journal 2014 13(Suppl 1): P95.
Submit your next manuscript to BioMed Central and take full advantage of:

- Convenient online submission

- Thorough peer review

- No space constraints or color figure charges

- Immediate publication on acceptance

- Inclusion in PubMed, CAS, Scopus and Google Scholar

- Research which is freely available for redistribution
() Biomed Central 